\title{
Enhancing Porters' Rights in Mountain Tourism: Mount Semeru in Bromo Tengger Semeru National Park
}

\author{
Angling Galih Cahaya Widiyanto* \\ Department of Hospitality, Politeknik eLBajo Commodus, Manggarai Barat, Indonesia
}

\begin{abstract}
This study aims to investigate the implementation of rights focusing on the policy and working practices of porters. A total of nine respondents, including two National Park employees, two tour operator representatives, and five porters, participated in the interviews. Data from observation and interviews analyzed through a qualitative descriptive paradigm. Overall interviews revealed that Bromo Tengger Semeru National Park policies have not adequately covered issues on portering activities. Existing policies are limited to the tariff, guided trekking, and organizational aspects of the porters' association. A high degree of effectiveness might be achieved through the involvement of related parties; however, that was not accessible. Some barriers in budgeting and communication appeared to determine that such policies are not yet effectively implemented. Involvement in policy making was indicated absent, since porters and stakeholders were not well facilitated. Monitoring and evaluation systems are carried alone by the National Park. In addition to that, the absence of policies on porters' working conditions has been indicated to contribute to unfavorable working conditions of porters, including excessive workloads and uncertain weight limitations.
\end{abstract}

Keywords: mountain tourism, Mount Semeru, porters.

\section{INTRODUCTION}

The increase of tourists and their demands for trekking activities believed as the two most important driving human rights issues on porters' practices. This phenomenon is seen as a social disadvantage where the host community regards tourism as an economic necessity that can create employment, yet a 'social evil' [1]. Tourism as a service industry is often criticized for being too ignorant with low paid employment and poor working conditions. Issues on human rights emerge from power differentials across stakeholders in destinations [2]. Problems arise from a measure of privileging human rights of certain tourism stakeholders over others. In the case of trekking activities, the privileged stakeholders often refer to tourists and tourism stakeholders who provide services to them. In support of this view, the rights of freedom to travel for tourists negatively affect the rights of people in destinations [3]. Furthermore, by the jargon 'Customer is King', it contested that tourists' rights are emphasized while other stakeholders are diminished [2,4]. Hence, the rights of local people placed in the second position to the needs of tourists at the destinations [5].

Meanwhile, one of the principles in tourism management, particularly in mountain tourism, is

\footnotetext{
*Correspondence address:

Angling Galih Cahaya Widiyanto

Email : angling@poltekelbajo.ac.id

Adress : Politeknik eLBajo Commodus, Kampung Lancang, Gang Ame Nompos, Wae Kelambu, Komodo, Manggarai Barat, Nusa Tenggara Timur, 86700
}

to ensure that sustainability contributed towards mountain livelihoods [6]. It is without a doubt that trekking activities benefit local communities, particularly in a higher mountain with an altitude of 3000 meters above the sea level where porters or carriers are needed. Freelance porters' role in mountain tourism, in this case, is really valuable, accompanying thousands of trekkers every year, carrying and even cooking three meals a day for the trekkers [7].

Aside from the benefit gained, porters even suffer more than the trekkers. Similar to trekkers, they also endure from heavy rains, strong winds, and altitude sickness. However, porters are rarely equipped with trekking gears and proper clothing [8]. While each trekker has to be checked for their equipment' safety, porters will not go through the same procedure. It is even common to see porters assembling a very simple shelter made of wood sticks and flysheets to sleep during the night. With the harsh condition of nature and inadequate equipment, as well as restless working hours during trekking, Reid quoted in a study, that up to 20 porters are estimated to die each year [9].

In Indonesia, portering practices are still conducted in several mountain regions [10]. One of those performed in Mount Semeru in Bromo Tengger Semeru National Park. It is estimated from the 600 trekking quota per day, around 200 thousand trekkers visit Mount Semeru every year [11]. It is because Mount Semeru stands as the highest peak in Java Island with the characteristics of a friendly destination offering camping site by a natural lake named Ranu 
Kumbolo in 2200 meters above sea level [12]. The mythology of Gods residing in Mount Semeru also contributes to its attractiveness. Evidence also appears to justify that National Park has been enhancing tourism activities as a strategy to support conservation for recent years $[13,14]$. This site offers an opportunity to study the livelihood of people in Ranu Pani Village who workpart-time as porters in Mount Semeru $[15,16]$. Thus, this present research meant to investigate the working conditions of porters operating in Mount Semeru and the effectiveness of current policies that protect their rights.

\section{MATERIAL AND METHOD \\ Data Collection \\ Observation}

The observation conducted following the trekking permission given by Bromo Tengger Semeru National Park authorities. At this stage, the author went for trekking with one porter from Ranu Pani Village who happened to connect the author with some porters in Mount Semeru. Initial contact was also made through interactions with the porters and allowed the author to gain their participation for the interview. Key informants were then selected and made to be available in the scheduled interview.

\section{Interviews}

Interviews were held in several locations, including National Park office, tour operator office, Mount Semeru basecamp, porters' houses, and food outlets. A combination of purposive and volunteer sampling was considered the most appropriate for this study. The purposive sampling utilized to select respondents from National Park authorities and tour operators. Volunteer sampling particularly using the snowball technique, allowed the porters to snowball where they nominated another porter in the population to join the interview.

National Park authorities interviewed to generate information on the implementation and monitoring of policies concerning porters' rights in Mount Semeru. Interviews with tour operators carried out to gather information on what extent tour operators are contributing to the promotion of porters' rights in National Park. Moreover, porters in Mount Semeru were also interviewed to find out the extent to which porters' rights have been ensured by National Park and to explore porters' involvement in the monitoring system of the policies.
Prior to the interview, informed consent was attained, which allowed participants' opinions and statements to be recorded. A total of nine participants consisting of two National Park authorities (Respondent CR and DV), two tour operators (Respondent $\mathrm{BR}$ and $\mathrm{JN}$ ), and five porters (Respondent BB, PL, PT, SM, and ST) were interviewed in this study. Several key themes that have been generated from the interviews are shown in Table 1.

Table 1. Key Themes Indicated in the Interviews

\begin{tabular}{lcccc}
\hline \multirow{2}{*}{$\begin{array}{c}\text { List of } \\
\text { Respondent }\end{array}$} & $\begin{array}{c}\text { Existence } \\
\text { of policy }\end{array}$ & $\begin{array}{c}\text { Involvement } \\
\text { in policy } \\
\text { discussion }\end{array}$ & $\begin{array}{c}\text { Monitoring } \\
\text { system }\end{array}$ & $\begin{array}{c}\text { Working } \\
\text { conditions }\end{array}$ \\
\cline { 2 - 5 } CR & $\checkmark$ & $\checkmark$ & $\checkmark$ & $\checkmark$ \\
DV & $\checkmark$ & $\checkmark$ & $\checkmark$ & $\checkmark$ \\
BR & $\checkmark$ & $\checkmark$ & & $\checkmark$ \\
JN & $\checkmark$ & $\checkmark$ & $\checkmark$ & $\checkmark$ \\
BB & $\checkmark$ & $\checkmark$ & $\checkmark$ & $\checkmark$ \\
PL & $\checkmark$ & $\checkmark$ & $\checkmark$ & $\checkmark$ \\
PT & $\checkmark$ & $\checkmark$ & $\checkmark$ & $\checkmark$ \\
SM & $\checkmark$ & $\checkmark$ & & $\checkmark$ \\
ST & $\checkmark$ & $\checkmark$ & & $\checkmark$ \\
\hline
\end{tabular}

Literature Study

A literature study was conducted to establish secondary data that supports the issue of this present research. The study also carried out to ensure the discussion expected to contribute to the understanding of portering activities especially in Mount Semeru. In terms of portering, previous research found that porters from Ranu Pani Village did not only act as carriers but also act as a lifesaver for accidents that happened in Mount Semeru [17]. They considered amateur as a lifesaver. However, their willingness to help is high. The literature also concluded that porters in Mount Semeru are reliable in case of rescue, and therefore they deserve periodic training as lifesaver [17].

In another literature, portering is found as a side job performed by people in the neighborhood of Mount Semeru. It also stated that portering is a form of people's participation in ecotourism promoted in Bromo Tengger Semeru National Park [10].

Discussions concerning porters of Mount Semeru found in several studies as above. However, this present research clearly has different issues. It focuses on investigating the working conditions of porters in Mount Semeru, the effectiveness of the current policies which protect their rights, and how the monitoring and evaluation of policies performed in Mount Semeru. Those issues are crucial since discussions on portering activities in Mount Semeru are barely found. 


\section{Data Analysis}

This study employed a qualitative descriptive paradigm with observation and interview data collection methods. This paradigm is regarded as suitable for the present study since it focuses on describing a contemporary phenomenon in the chosen field [18].

\section{RESULT AND DISCUSSION \\ Policy Practice and Its Monitoring System \\ Policy concerning Porters' Rights}

Tourism destinations cannot be separated from their administrative function to raise issues into policy [19]. Concerns have been dragged into portering activities in Mount Semeru. However, National Park employee believed, by this far, a few actions involve policies in trekking activities that have manifested porters as the objects. It was also confirmed by Respondent DV as the National Park employee during the interview, that in general, policies established to reduce risks and reach optimum outcomes that benefit all parties within trekking activities in Mount Semeru. Respondent DV also stated that policies include policy on tariff, establishment of porters' association, and policy on the guided trekking, where each trekking group has to be accompanied by at least one porter:

"I heard of it, that every trekker has to be accompanied by one porter, that is one of those policies, next is the establishment of porters' association and it has its authorised basis."

The above arguments imply that particular action is the presentation of policy within National Park [20]. In contrast, the involvement of porters in the discussion reflected the policies in National Park were not always formulated by public authorities alone but rather set by parties involved in the implementation of such policies [21]. It justifies that policies taken are indeed made to deal with 'problems, concerns, and opportunities' of the porters [21]. Furthermore, involving porters in the discussion of such policies is suggested [22]. By having them together in the discussions, they expected to gain a common understanding and effective implementation of such policies. Ideally, interests of porters and National Park can be mutually achieved. However, the level of education and way of communication sometimes hinder porters from their participation in the discussion. Respondent PT, who is a porter in Mount Semeru, admitted clearly during the interview:

"Honestly, we need those, but I am [silent] lack of confidence, and a bit shy, so I actually want to participate, but I have no courage."
Monitoring System of the Policy Practice

Consistent with Hall and Jenkins, monitoring and evaluation wereperformed by National Park [23]. Monitoring was normally done on an interval basis, whereas evaluation conducted at the end of the term of policy implementation. Consequently, this finding comes in the same spirit with Dye, where evaluation focused on the performance of policy practice [24]. Concerning the monitoring and evaluation of the policy, Respondent CR explained National Park incorporates both actions to asses the policy effectiveness.

"We, as the management of National Park, do both monitoring and evaluation concerning portering activities, we do monitor and evaluate the tour operators and porters."

Notwithstanding, the performance of tour operators in both the monitoring and evaluation of the policies did not seem to be facilitated. Both tour operators even argued, that most likely they merely received an announcement on the closing and opening period of Mount Semeru. Other information concerning trekking and porters, in particular, was achieved from the discussion with a local guide. It was not that astonishing since tour operators providing trekking activities in Mount Semeru came from different regions of the country. Having them in one place for evaluation purposes might be a difficult task for the National Park, whereas meeting the objectives of ensuring protection of human rights in trekking activities can optimally be achieved by the involvement of all parties [12, 25]. Moreover, since previous discussions show that policies concerning porters are limited to the tariff, guided trekking, and porters' association, it can be argued that the involvement of tour operators in those particular matters are not substantial. JN as tour operator answered on their involvement in the monitoring system.

"Normally, more into community to community, for example, National Park text porter association, porter association then text to the group and disperse it to local operators, from local operators then we who live in Jakarta receive the latest."

Working Conditions of Porters in Mount Semeru

Hall and Brown argue that porters should be paid by a 'fair compensation' [26]. Roemer also expressed his stance that compensation can come with responsibility; hence it depends on the practices [27]. Regarding portering, it can be concluded that the conditions associated with their loads, workloads, and tariff (Table 2). 
Table 2.Portering Practices in Mount Semeru

\begin{tabular}{ll}
\hline \multicolumn{1}{c}{ Issues } & \multicolumn{1}{c}{ Conditions } \\
\hline Loads & $\begin{array}{l}25 \text { kilograms } \\
\text { Navigating, assembling tent, cooking, } \\
\text { and rescuing } \\
200.000-250.000 \text { Rupiah }\end{array}$ \\
Tariff &
\end{tabular}

Interviews revealed that maximum loads to be carried by a porter in Mount Semeru are 25 $\mathrm{kg}$. It is according to the common practice agreed among porters, tour operators, and trekkers. Some still tolerate the weights up to 30 kgbecause they do not want to lose their customers. A porter clearly explained that:

"The limitation is between 20 to $25 \mathrm{~kg}$ for a porter to carry. If it is up to $30 \mathrm{~kg}$, it depends on the porter, if he needs money then he will carry, he will not refuse it."

Meanwhile, both operators disclosed that they normally operate a ratio system rather than a weighting system of the loads. In this case, operators set their own ratio on how many porters they hire:

"One porter for four trekkers or one porter for five trekkers, I normally divide that way."

The above statement also reflected from another tour operator:

"One porter for two foreigners, for four domestic people, it depends on the loads indeed. We also asked them how many liters they carry, sometimes for one customer, we hire two porters."

Most respondents agreed that the number has been deliberately decided among porters in the association. Such finding justifies that $25 \mathrm{~kg}$ is acceptable and also applicable in another destination, such as Kilimanjaro, where $25 \mathrm{~kg}$ are set as the official limit for loads in mountain trekking [6]. The number remained untraceable. Porters are unsure whether it was researched or taken from some aspects such as academic, health, or psychology. However, the code of ethics in trekking activities has suggested $25 \mathrm{~kg}$ as the maximum weight that can be borne out physically by a man [28]. Tourism Concern also suggests that weight limits may need to be flexible due to the altitude, trail, and weather conditions. Thus, adjustment is required in order to keep the safety of porters[28].

It was also evident from the interview that overweight loads are still tolerated by the porters [29]. As the scale is not available at the entrance point, loads were not weighed properly. It is line with the theory that unavailability of pre-trek weighing causes overweight [30]. It leads to inaccuracy to occur.Inappropriate hiring system also contributes to the overweight where tour operators distribute the loads only to few numbers of porters, while the loads shall be carried by more porters. It was confirmed by Respondent PT that when a porter needs money, he will just carry those overweight loads. Otherwise, he will lose his customer. Nevertheless, the last cause of overweight does not seem to take place in Mount Semeru, in which porters were usually bribed to carry more than $25 \mathrm{~kg}$, as none of porters admitted that during the interview.

\section{Workloads}

It is necessary to mention at this point that majority of respondents have no additional options to deal with seasonality in agriculture except joining the portering activities [31]. This condition is following the premise raised by Hall and Brownconcerning people living in the mountain region [26]. The interview allowed respondents to state about porters' working conditions in Mount Semeru, showing that their workloads are complicated and burdensome. Such conditions have been verified by the tour operator in the following statement:

"It should be noted that their works are to carry our loads for a maximum of $25 \mathrm{~kg}$, secondly, assembling the tent, and next is looking for water resources. Helping us in navigation, I mean that they actually do navigation but not as essential as the guide. However, as long as they can carry $25 \mathrm{~kg}$ of loads, then that is okay, and helping us if we have difficulties or when we are ill."

Porters also observed that their jobs are not limited to carrying loads of the trekker, it is more than that, as one of them admitted:

"We do the cooking, looking for clean water in Kalimati (2700 masl). In Kalimati, the journey to get into water resources is up to 30 minutes away, and the return can be more than 30 minutes."

In case of emergency, they even believe that only porters can do the rescue as they are familiar with the mountain condition. Lack of cleaning and security officers in the registration area, as well as the entrance gate, also encouraged them to join the works which indicated through the statement by BB:

"Going back to the village is so time-consuming and people who work here (in the registration area) are limited too, so we (porters), do the cleaning, security as well as checking trekkers' items."

It was found that their reasons to do so is due to their sense of responsibility for the customers and the common practice that embedded by their association that trekkers are their customers who should be treated well. It was 
also indicated during the interview, as they continuously addressed trekkers as customers.

Such orientation disregards others' rights through the consumption of one's physical abilities, which in the end, are valued by money. Then, it is obvious to say that the slogan 'Customer is the King' has been attached to portering activities. It is also consistent with the theory that freedom of travel has been integrated into the freedom to consume $[4,5]$.

Tariff

In terms of tariff, different trekking destinations might apply different portering tariffs. In this particular practice, the tour operator has set its own budget for one porter per day. They also admitted that the tariff is increasing each year and sometimes based on the trekking seasonality in Mount Semeru. During national holiday, porters' tariff is believed to increase up to IDR 50,000 from its usual tariff. However, one tour operator has set its tariff higher than the normal tariff as he admitted:

"For instance, I have a budget for IDR 250,000, but they set IDR 240,000, then I will pay IDR 200,000 as long as they can provide extra service.l meant, they did not ignore the customers, because most likely just walk away."

Meanwhile, another respondent remained to the usual tariff expecting porters to be responsible for everything because, in practice, this respondent used to have certain treatment or services from porters. It might be argued that tariff is just an amount that needs to be paid at the end of the portering services. The considerations to pay also lie on the budget provided by customers, which normally set as a minimum tariff. The respondents emphasize more on what services porters can give from that payment. Thus, giving an extra amount of money means that porters are expected to conduct more works rather than just carrying the loads. Such practice is contrary to the proposition in which giving 'fair compensation' for porters is essential to generate income for them rather than to encourage porters to have more workloads during the trekking [26].

\section{CONCLUSION}

National Park policy concerning the protection of porters' rights is almost absent from existence. National Park has not yet manifested their concerns into porters' rights issue. The existing policies are limited to regulate porters' tariff, porters' association, and guided trekking, which also found effectively implemented to date. Both monitoring and evaluation system was conducted regarding the existing policies. However, those are carried independently by National Park.

Porters were found overwhelmed by the workloads that have been practiced for a long time so that those workloads are already attached to the common practices in Mount Semeru. Moreover, their sense of responsibility toward customers has resulted in excessive loads, not just limited to carrying the loads. The absence of policy concerning portering activities in Mount Semeru has indeed contributed to their poor working conditions.

To improve the protection of porters' rights, as well as enhancing policies'monitoring systems within Mount Semeru in the future, National Park is suggested to take the following measures in the form of policy. They need to provide work equipment for porters, provide insurance for porters, establish pre-trek checking policies, encourage the establishment of porters' policy to tour operators, collaborate with NGOs and related institutions to provide training for portersand, engage knowledge of best practice about portering.

\section{Acknowledgement}

The author acknowledged Bromo Tengger Semeru National Park authorities for the permission given to conduct this research as well as the discussions held during the time given. The author also appreciates the time and information given by tour operators and porters of Mount Semeru involved in the data collection.

\section{REFERENCES}

[1] French, C. N., S. J. Craig-Smith, and A. Collier. 1995. Principles of tourism. Longman. Melbourne.

[2] Scheyvens, R. 2011. Tourism and poverty. Routledge. New York.

[3] Singh, S., Timothy, D. J. and Dowling, R. K. 2003. Tourism in destination communities. CABI. Wallingford.

[4] Branson, R. and Craven, R. 2002. Customer is king: How to exceed your clients' expectations. Virgin Books. New York.

[5] George, B. P. and Varghese, V. 2007. Human rights in tourism: conceptualization and stakeholder perspectives. EJBO - Electronic Journal of Business Ethics and Organization Studies 12(2), 40-48.

[6] Sati, V. P. 2014. Towards sustainable livelihoods and ecosystems in mountain 
regions. Environmental Science and Engineering. Springer. Cham.

[7] Frohlick, S. 2004. 'Who is Lhakpa Sherpa?'circulating subjectivities within the global/local terrain of himalayan mountaineering. Social and Cultural Geography 5(2), 195-212.

[8] Peaty, D. 2012. Kilimanjaro tourism and what it means for local porters and for the local environment. Journal of Ritsumeikan Social Sciences and Humanities4, 1-11.

[9] Christie, I., Fernandes, E., Messerli, H. and Twinning-Ward, L. 2014. Tourism in Africa: harnessing tourism for growth and improved livelihoods. The World Bank. Washington.

[10] Purwanti, R. 2018. Effectiveness of local people's perception on ecotourism participation in Bromo Tengger Semeru National Park, Indonesia. Jurnal IImiah Administrasi Publik (JIAP) 4(3), 263-274.

[11] Bromo Tengger Semeru National Park. 2019. Head of Bromo Tengger Semeru National Park's Decree Number SK./T.8/BIDTEK/BIDTEK.1/KSA/4/2019 on Standar Operasional Prosedur (SOP) for Climbing Activities in Mount Semeru in Bromo Tengger Semeru National Park. Available at: https://bookingsemeru. bromotenggersemeru.org/index/tatacara.

[12] Hakim, L. and Soemarno, M. 2017. Biodiversity conservation, community development and geotourism development inBromo-Tengger-Semeru-Arjuno biosphere reserve. GeoJournal of Tourism and Geosites 20(2), 220-230.

[13] Lindberg, K. and D. E. Hawkins. 1993. Ecotourism: a guide for planners and managers. The Ecotourism Society.

[14] Hakim, L. 2011. Cultural landscapes of the Tengger Highland, East Java. In: Landscape Ecology in Asian Cultures. Springer. Tokyo. 69-82.

[15] Astriyantika, M., H. Arief and T. Sunarminto. 2014. Studi konservasi sumberdaya alam hayati pada Masyarakat Tengger di Resort Ranu Pani, Taman Nasional Bromo Tengger Semeru. Media Konservasi 19(1), 1-11.

[16] Budiyanti, S. 2015. Analisis deskriptif aktivitas dan potensi komunitas Desa 'Enclave' Ranu Pane pada zona pemanfaatan tradisional, Kecamatan Senduro, Kab. Lumajang, Wilayah Taman Nasional Bromo Tengger Semeru (TNBTS). DIMENSI - Journal of Sociology 8(2), 1-11.
[17] Hupitoyo. 2019. Pemberdayaan komunitas pengemudi jeep dan porter dalam menekan angka kecacatan akibat kecelakaan wisata di Taman Nasional Bromo Tengger Semeru (TNBTS) Jawa Timur. Jurnal Idaman 1(1),5-9.

[18] Aspers, P. and U. Corte. 2019. What is qualitative in qualitative research? Qualitative Sociology 42(2), 139-160.

[19] Holden, A. 2016. Environment and Tourism. Routledge. Abingdon.

[20] Whitford, M., B. Bell, and M. Watkins. 2001. Indigenous tourism policy in Australia: 25 years of rhetoric and economic rationalism. Current Issues in Tourism 4, 151-181.

[21] Airey, D. and K. Chong. 2010. National policy-makers for tourism in China. Annals of Tourism Research 37(2), 295-314.

[22] Dredge, D. and J. Jenkins. 2007. Tourism planning and policy. John Wiley. Milton.

[23] Hall, C. and J. Jenkins. 1995. Tourism and public policy. Routledge. London.

[24] Dye, T. R. 2008. Understanding public policy. Pearson Prentice Hall. New Jersey.

[25] The World Conservation Union (IUCN). 1996. Collaborative management of protected areas: tailoring the approach to the context. IUCN. Gland.

[26] Hall, D. R. and F. Brown. 2006. Tourism and welfare: ethics, responsibility and sustained well-being. CABI. Wallingford.

[27] Roemer, J. E. 1993. A pragmatic theory of responsibility for the egalitarian planner. Philosophy and Public Affairs 22(2), 146166.

[28] Cater, C. I., B. Garrod, and T. Low. 2015. The encyclopedia of sustainable tourism.CABI. Wallingford.

[29] Mafuru, N., J. Wakibara, and K. Ndesari. 2009. Tourism-related impacts on Mount Kilimanjaro, Tanzania: Implications for tourism management on mountain ecosystems. Journal of Tourism Challenges and Trends 2(1), 111-123.

[30] Ndekirwa, P., D. Mtuy, J. Bernard, K. Valenti, and R. Forrest. 2011. Kilimanjaro porters assistance project monitoring report porter surveys 2010. Available at: http://www. fairtravel.com/wp-content/uploads/2012/ 11/Kilimanjaro-Porters-Assistance-ProjectData-Summary-Report.pdf.

[31] Haliim, W. 2018. Dinamika implementasi kebijakan konservasi lahan Taman Nasional Bromo Tengger Semeru. Journal Borneo Administrator 14(1), 53-68. 